Jurnal Semarak,Vol. 3,No.1, Februari 2020, Hal (111- 122)

\title{
PENGARUH CURRENT RATIO (CR) DAN DEBT TO ASSETS RATIO (DAR) TERHADAP RETURN ON ASSETS (ROA) \\ (Studi Kasus pada PT.Electronic City Tbk yang Terdaftar Di Bursa Efek Indonesia Tahun 2008-2017)
}

\author{
Shelby Virby \\ Staf Pengajar Fakultas Ekonomi Universitas Pamulang \\ Email: shelbykapoyos@gmail.com
}

\begin{abstract}
ABSTRAK
Tujuan dari penelitian yankg dilakukan adalah untuk mengetahui current ratio pada PT. Electronic City, Tbk, untuk mengetahui debt to assets ratio pada PT. Electronic City, Tbk, untuk mengetahui return on assets pada PT. Electronic City, Tbk. Dan untuk mengetahui current ratio dan debt to assets ratio terhadap return on assets pada PT. Electronic City, Tbk. Objek dalam penelitian ini adalah PT. Electronic City, Tbk.yang terdaftar di Bursa Efek Indonesia (BEI). Metode yang digunakan pada penelitian ini adalah metode deskriptif dengan menggunakan pendekatan asosiatif. Data yang digunakan adalah data sekunder, yang diperoleh dari situs www.idx.co.id. Pengelolaan data diolah dengan menggunakan program software Statistical Product and Service Solution (SPSS) versi 20.0, analisis data yang digunakan adalah uji asumsi klasik, analisis regresi linear berganda, koefisien determinasi, dan uji t serta uji f. Berdasarkan data yang diperoleh, hasil pengujian asumsi klasik bahwa data berdistribusi normal, tidak terjadi multikolinearitas, tidak terjadi heteroskedastisitas dan tidak ada autokorelasi. Hasil dari analisis regresi linear berganda yaitu $\mathrm{Y}=32,756-$ $0,026 X_{1}-0,291 X_{2}+\varepsilon$. Hasil pengujian determinasi menunjukan bahwa Current Ratio (CR) dan Debt to Assets Ratio (DAR) dapat menjelaskan Return On Assets (ROA) sebesar 40,4\% sedangkan sisanya 59,6\% dipengaruhi oleh variabel lain yang tidak dijelaskan didalam penelitian ini. Berdasarkan hasil uji t menunjukan bahwa secara parsial variabel Current Ratio (CR) tidak terdapat pengaruh signifikan terhadap Return On Assets (ROA) dimana $\mathrm{T}_{\text {hitung }}<\mathrm{T}_{\text {tabel }}(-2,167<$ 2,306) Diperoleh signifikansi 0,067>0,05 Sedangkan secara parsial Debt to Assets Ratio (DAR) tidak terdapat pengaruh signifikan terhadap Return On Assets (ROA) dimana $\mathrm{T}_{\text {hitung }}<\mathrm{T}_{\text {tabel }}(-1,871<2,306)$ diperoleh signifikansi 0,103 > 0,05 Berdasarkan hasil uji $\mathrm{F}$ menunjukan bahwa secara simultan Current Ratio (CR) dan Debt to Assets Ratio (DAR) tidak terdapat pengaruh signifikan terhadap Return On Assets (ROA) dimana $F_{\text {hitung }}<F_{\text {tabel }}(2,373<$ 4,74) diperoleh signifikansi $(0,163>0,05)$.
\end{abstract}

\section{Kata kunci: Current Ratio, Debt to Assets Ratio, Return On Assets}




\begin{abstract}
The purpose of the research carried out is to determine the current ratio at PT. Electronic City, Tbk, to find out the debt to assets ratio at PT. Electronic City, Tbk, to find out return on assets at PT. Electronic City, Tbk. And to find out the current ratio and debt to assets ratio to return on assets at PT. Electronic City, Tbk. The object of this research is PT. Electronic City, Tbk. Which is listed on the Indonesia Stock Exchange (IDX). The method used in this research is descriptive method using an associative approach. The data used is secondary data, obtained from the site www.idx.co.id. Data management is processed using Statistical Product and Service Solution (SPSS) software version 20.0, data analysis used is the classic assumption test, multiple linear regression analysis, coefficient of determination, and t test and f test. Based on the data obtained, the results of testing the classic assumption that the data are normally distributed, does not occur multicollinearity, heteroscedasticity does not occur and there is no autocorrelation. The results of multiple linear regression analysis are $Y=32.756-0.026 X 1-0.291 X 2+\varepsilon$. Determination test results show that the Current Ratio (CR) and Debt to Assets Ratio (DAR) can explain the Return On Assets (ROA) of $40.4 \%$

while the remaining $59.6 \%$ is influenced by other variables not explained in this study. Based on the results of the t test showed that partially the Current Ratio (CR) variable had no significant effect on Return On Assets (ROA) where Thitung

$<$ Ttable $(-2,167<2,306)$ Obtained a significance of 0.067>0.05 While partially Debt to Assets Ratio (DAR) there is no significant effect on Return On Assets (ROA) where Thitung <Ttable $(-1.871<2.306)$ obtained significance 0.103> 0.05 Based on the results of the F test shows that the simultaneous Current Ratio (CR) and Debt to Assets Ratio (DAR)) there is no significant effect on Return On Assets (ROA) where Fcount <Ftable (2.337 <4.74) obtained significance $(0.163>0.05)$.
\end{abstract}

\title{
Keywords: Current Ratio, Debt to Assets Ratio, Return On Assets
}


Jurnal Semarak,Vol. 3,No.1, Februari 2020, Hal (1- 19)

@Prodi Manajemen Fakultas Ekonomi Universitas Pamulang

\section{PENDAHULUAN}

\section{A. Latar Belakang}

Seiring dengan perkembangan perekonomian saat ini, menimbulkan persaingan dalam dunia bisnis yang semakin ketat sehigga menjadikan suatu perusahaan untuk menampilkan performa terbaik yang akan berdampak terhadap kepercayaan investor untuk menanamkan modalnya dan mempermudah perusahaan dalam memperoleh dana atau tambahan modal dengan menjual sahamnya kepada para investor atau masyarakat melalui pasar modal. Adanya pasar modal bagi para investor merupakan wadah yang dapat digunakan untuk menginvestasikan dananya dan juga dapat memberikan kesempatan untuk mengoptimalkan keuntungan investasi menjadi semakin besar. Pasar modal merupakan pasar dimana terjadi transaksi jual beli aktiva keuangan berupa surat surat berharga pendapatan tetap (fixed income securities) dan saham saham (equity securities) untuk investasi jangka panjang (Jogiyanto, 2014: 8). Tujuan investor menanamkan dananya pada sekuritas saham tentunya untuk memperoleh tingkat pengembalian (return) tertentu dengan risiko minimal. Investor dapat memperoleh keuntungan yang banyak, begitu juga sebaliknya dapat mengalami kerugian yang tidak sedikit. Hal tersebut yang menyebabkan investasi pada saham merupakan investasi yang beresiko tinggi Investor tidak hanya dituntut untuk jeli tetapi juga harus berhati-hati dalam pengambilan keputusan investasi dengan terlebih dahulu menganalisis secara teliti dan cermat saham-saham yang akan dibeli dengan didukung menggunakan data-data yang akurat untuk dapat memilih investasi yang aman. Untuk mendapatkan data-data yang akurat dapat dilihat dari laporan keuangan perusahaan tersebut. Laporan keuangan merupakan sebuah media informasi yang mencatat, merangkum segala akivitas perusahaan dan digunakan untuk melaporkan keadaan dan posisi perusahaan pada pihak yang berkepentingan, terutama pada pihak kreditur, investor, dan untuk manajemen perusahaan itu sendiri. Untuk menggali lebih banyak lagi informasi yang terkandung dalam suatu laporan keuangan diperlukan suatu analisis laporan keuangan. Apabila suatu informasi disajikan dengan benar, informasi tersebut sangat berguna bagi perusahaan dalam pengambilan keputusan dan untuk mengetahui kinerja perusahaan. Evaluasi kineja keuangan dapat dilakukan menggunakan analisis laporan keuangan. Dimana analisis laporan keuangan dapat dilakukan menggunakan rasio keuangan. Rasio keuangan secara garis besar dikelompokkan menjadi lima yaitu rasio likuiditas, rasio aktivitas, rasio profitabilitas, rasio solvabilitas (leverage) dan rasio pasar. Rasio profitabilitas merupakan rasio yang digunakan untuk mengukur kemampuan perusahaan dalam menghasilkan keuntungan. Megingat tujuan setiap usaha bisnis adalah untuk meraih laba, maka rasio-rasio yang menunjukkan kemampuan perusahaan dalam menghasilakan laba (profitabilitas) akan mencerminkan tingkat efektifitas pengelolaan yang dilakukan oleh 
manajemen perusahaan. Salah satu rasio profitabilitas yang menarik perhatian investor adalah Return On Assets (ROA). Menurut Kasmir (2008:201) Return On Assets merupakan rasio yang menunjukan hasil (return) atas jumlah aktiva yang digunakan dalam perusahaan. ROA merupakan pengukuran kemampuan perusahaan secara keseluruhan di dalam mengahasilkan keuntungan dengan jumlah keseluruhan aktiva yang tersedia di dalam perusahaan. Semakin besar ROA menunjukkan kinerja yang semakin baik, karena tingkat kembalian semakin besar. Dengan meningkatnya kinerja perusahaan, maka harga saham perusahaan di pasar modal meningkat dan hal ini berdampak pada peningkatan return saham. Ketertarikan investor pada perusahaan yang menghasilkan ROA tinggi mendorong peningkatan permintaan kepemilikan saham sehingga harga saham perusahaan menjadi meningkat. Rasio Likuiditas yang digunakan dalam penelitian ini ialah Current Rasio atau biasa disebut Rasio Lancar. Menurut Kasmir (2015:134), menerangkan bahwa Rasio lancar (Current ratio) merupakan rasio untuk mengukur kemampuan perusahaan dalam membayar kewajiban jangka pendek atau utang yang segera jatuh tempo pada saat ditagih secara keseluruhan.

Current ratio menunjukkan sejauh mana akitva lancar menutupi kewajibankewajiban lancar. Semakin besar perbandingan aktiva lancar dan kewajiban lancar semakin tinggi kemampuan perusahaan menutupi kewajiban jangka pendeknya. Current ratio yang rendah biasanya dianggap menunjukkan terjadinya masalah dalam likuidasi, sebaliknya current ratio yang terlalu tinggi juga kurang bagus, karena menunjukkan banyaknya dana menganggur yang pada akhirnya dapat mengurangi kemampuan laba perusahaan. Menurut Kasmir (2015:156) Debt to Total Assets Ratio(DAR) digunakan untuk mengukur perbandingan antara total utang dengan total aktiva. Dengan kata lain, seberapa besar aktiva perusahaan dibiayai oleh utang atau seberapa besar utang perusahaan berpengaruh terhadap pengelolaan aktiva. Debt to Total Assets Ratio (DAR) adalah salah satu rasio yang digunakan untuk mengukur tingkat solvabilitas perusahaan. Tingkat solvabilitas perusahaan adalah kemampuan perusahaan untuk membayar kewajiban jangka panjang perusahaan tersebut. Suatu perusahaan dikatakan solvabel berarti perusahaan tersebut memiliki aktiva dan kekayaan yang cukup untuk membayar hutang-hutangnya. Rasio ini menunjukkan besarnya total hutang terhadap keseluruhan total aktiva yang dimiliki oleh perusahaan. Rasio ini merupakan persentase dana yang diberikan oleh kreditor bagi perusahaan. Rasio hutang bisa berarti buruk pada situasi ekonomi sulit dan suku bunga tinggi, dimana perusahaan yang memiliki rasio hutang yang tinggi dapat mengalami masalah keuangan, namun selama ekonomi baik dan suku bunga rendah maka dapat meningkatkan keuntungan. Nilai rasio yang tinggi menunjukkan peningkatan dari resiko pada kreditor berupa ketidakmampuan perusahaan membayar semua kewajibannya Mengingat kondisi ekonomi yang selalu mengalami perubahan, 
maka dapat mempengaruhi kondisi perusahaan yang dapat dilihat dari labanya. Laba perusahaan yang harusnya meningkat, justru sebaliknya mengalami penurunan. Kondisi tersebut sebagai sebab penelitian ini dilakukan, disamping alasan lain yaitu untuk mengetahui apakah penelitian ini konsisten dengan penelitian sebelumnya.

\section{B. Perumusan Masalah}

Berdasarkan latar belakang yang telah dikemukakan sebelumnya, maka permasalahan yang akan diajukan dalam penelitian ini adalah:

1. Bagaimana pengaruh Current Ratio (CR) terhadap Return On Assets (ROA) pada PT.Elektronik City pada tahun 2008 - 2017 ?

2. Bagaimana pengaruh Debt to Assets Ratio (DAR) terhadap Return On Assets (ROA) pada PT.Elektronik City pada tahun 2008 - 2017 ?

3. Berapa besar pengaruh Current Ratio (CR) dan Debt to Assets Ratio (DAR) secara bersama-sama terhadap Return On Assets (ROA) pada PT.Elektronik City pada tahun $2008-2017$ ?

\section{Tujuan Penelitian}

Tujuan penelitian ini adalah untuk memberikan jawaban atas pertanyaan khusus di atas. Adapun tujuan penelitian adalah:

a. Untuk mengetahui pengaruh Current Ratio (CR) terhadap Return On Assets (ROA) pada PT.Electronic City yang tercatat di BEI periode 2008- 2017.

b. Untuk mengetahui pengaruh Debt to Assets Ratio (DAR) terhadap Return on Assets (ROA) pada PT.Electronic City yang tercatat di BEI periode 2008- 2017.

c. Untuk mengetahui seberapa besar pengaruh Current Ratio (CR) dan Debt to Assets Ratio (DAR) secara bersama-sama terhadap Return On Assets (ROA) pada PT.Electronic City yang tercatat di BEI periode 2008- 2017.

\section{TINJAUAN PUSTAKA}

\section{A. Pengertian Manajemen Keuangan}

Pengertian Manajemen Keuangan Menurut Sutrisno (2013:3) mengemukakan bahwa : "Manajemen keuangan dapat diartikan sebagai semua aktivitas perusahaan yang berhubungan dengan usaha-usaha mendapatkan dana perusahaan dengan biaya yang murah serta usaha untuk menggunakan dan menfgalokasikan dana tersebut secara efisen". Manajemen keuangan memainkan peranan penting dalam perkembangan sebuah perusahaan. Dalam penerapannya, manajemen keuangan tidak 
JURNAL IIMAAH $\quad$ P-ISSN 2615-6849, E-ISSN 2622-3686

Jurnal Semarak,Vol. 3,No.1, Februari 2020, Hal (1 - 19)

@Prodi Manajemen Fakultas Ekonomi Universitas Pamulang

dapat berdiri sendiri. Manajemen keuangan selain berkaitan erat dengan berbagai ilmu yang lain seperti akutansi, ilmu ekonomimikro dan makro, manajemen pemasaran, manajemen produksi dan sumber daya manusia. 


\section{B. Current Ratio}

\section{a. Pengertian Curent Ratio}

Menurut Sutrisno (2012:60) Current Ratio adalah: "Rasio yang membandingkan antara aktiva lancar yang dimiliki perusahaan dengan hutang jangka pendek. Hutang jangka pendek disini meliputi hutang dagang, hutang wesel, hutang bank, hutang gaji, dan hutang lainnya yang segera harus dibayar".

Current Ratio (CR) menurut Fahmi (2011:121) adalah "ukuran yang umum digunakan atau solvensi jangka pendek, kemampuan suatu perusahaan memenuhi kebutuhan hutang ketika jatuh tempo".

Menurut Kasmir (2015:134), menerangkan bahwa Rasio lancar (Current ratio) merupakan rasio untuk mengukur kemampuan perusahaan dalam membayar kewajiban jangka pendek atau utang yang segera jatuh tempo pada saat ditagih secara keseluruhan. Current ratio yang rendah menunjukkan bahwa likuiditas perusahaan buruk. Sebaliknya jika current ratio relatif tinggi, likuiditas perusahaan relatif baik. Namun harus dicatat bahwa tidak pada semua kasus dimana current ratio tinggi, likuiditas perusahaan pasti baik. Meskipun aktiva lancar lebih besar dari hutang lancar, perlu diingat bahwa item-item aktiva lancar seperti persediaan dan piutang terkadang sulit ditagih atau dijual secara tepat.

\section{b. Faktor-faktor yang mempengaruhi Current ratio}

Current ratio yang terlalu tinggi menunjukkan kelebihan uang kas atau aktiva lancar lainnya dibandingkan dengan yang dibutuhkan sekarang atau tingkat likuiditas yang rendah daripada aktiva lancar dan sebaliknya. Menurut Munawir (2004:72) penganalisa sebelum membuat kesimpulan yang akhir dari analisa current ratio harus mempertimbangkan faktor- faktor sebagai berikut :

- Distribusi atau proporsi daripada aktiva lancar,

- Syarat yang diiberikan oleh kreditor kepada perusahaan dalam mengadakan pembelian maupun syarat kredit yang diberikan oleh perusahaan dalam menjual barangnya,

- Present value (nilai sesungguhnya) dari aktiva lancar, sebab ada kemungkinan perusahaan mempunyai saldo piutang yang cukup besar tetapi piutang tersebut sudah lama terjadi dan suliit ditagih sehingga nilai realisasinya mungkin lebih kecil dibandingkan dengan yang dilaporkan,

- Kemungkinan perubahan nilai aktiva lancar, kalau nilai persediaan semakin turun (deflasi) maka aktiva lancar yang besar (terutama ditunjukkan dalam persediaan) maka tidak menjamin likuiditas perusahaan,

- Perubahan persediaan dalam hubungannya dengan volume penjualan sekarang atau di masa yang akan datang, yang mungkin adanya over investment dalam persediaan, 
- Kebutuhan jumlah modal kerja di masa mendatang, makin besar kebutuhan modal kerja di masa yang akan dating maka dibutuhkan adanya ratio yang besar pula,

- Type atau jenis perusahaan (perusahaan yang memproduksi sendiri barang yang dijual, perusahaan perdagangan atau perusahaan jasa).

\section{C.Debt to Assets Ratio}

Menurut Kasmir (2015:156) Debt to Assets Ratio(DAR) digunakan untuk mengukur perbandingan antara total utang dengan total aktiva. Dengan kata lain, seberapa besar aktiva perusahaan dibiayai oleh utang atau seberapa besar utang perusahaan berpengaruh terhadap pengelolaan aktiva.

Debt to Assets Ratio menurut Fahmi (2011:127) : Rasio yang melihat perbandingan utang perusahaan, yaitu diperoleh dari perbandingan total utang dibagi total aset. Sehingga dapat disimpulkan bahwa rasio ini mengukur presentase besarnya dana yang berasal dari hutang baik jangka pendek maupun jangka panjang. Kreditur lebih menyukai Debt to Assets Ratio yang rendah sebab tingkat keamanannya semakin baik.

\section{Return On Assets}

\section{a. Pengertian Return On Assets}

Menurut Kasmir (2014:201) yaitu "Return On Total Assets merupakan rasio yang menunjukkan hasil (return) atas jumlah aktiva yang digunakan dalam perusahaan". Menurut Brigham dan Houston (2010:148) mengatakan bahwa ROA adalah "rasio laba bersih terhadap total aset mengukur pengembalian atas total aset". Menurut Fahmi (2012:98) pengertian return on assetsyaitu:Return on assets sering juga disebut sebagai return on investment, karena ROA ini melihat sejauh mana investasi yang telah ditanamkan mampu memberikan pengembalian keuntungan sesuai dengan yang diharapkan dan investasi tersebut sebenarnya sama dengan aset perusahaan yang ditanamkan atau ditempatkan. Berdasarkan definisi menurut para ahli tersebut, maka dapat disimpulkan bahwa return on assets (ROA) merupakan rasio profitabilitas yang digunakan untuk mengukur efektivitas perusahaan dalam menghasilkan keuntungan dengan memanfaatkan aktiva yang dimilikinya.

Analisis ROA mengukur kemampuan perusahaan dalam menghasilkan laba dengan menggunakan kekayaan (total assets) yang dimiliki perusahaan yang bersangkutan setelah disesuaikan dengan biaya- biaya yang mendanai asset tersebut.

b. Fungsi Return On Assets 
Menurut Munawir (2007;91) kegunaan dari analisa Return On Assets dikemukakan sebagai berikut : Sebagai salah satu kegunaannya yang prinsipil ialah sifatnya yang menyeluruh. Apabila perusahaan sudah menjalankan praktek akuntansi yang baik maka manajemen dengan menggunakan teknik analisa Return On Assets dapat mengukur efisiensi penggunaan modal yang bekerja, efisiensi produksi dan efisiensi bagian penjualan.

- Apabila perusahaan dapat mempunyai data industri sehingga dapat diperoleh rasio industri, maka dengan analisa Return On Asset dapat dibandingkan efisiensi penggunaan modal pada perusahaannya dengan perusahaan lain yang sejenis, sehingga dapat diketahui apakah perusahaannya berada di bawah, sama, atau di atas rata-ratanya. Dengan demikian akan dapat diketahui dimana kelemahannya dan apa yang sudah kuat pada perusahaan tersebut dibandingkan dengan perusahaan lain yang sejenis.

- Analisa Return On Asset juga dapat digunakan untuk mengukur efisiensi tindakan-tindakan yang dilakukan oleh divisi/bagian yaitu dengan mengalokasikan semua biaya dan modal ke dalam bagian yang bersangkutan. Arti pentingnya mengukur rate of return pada tingkat bagian adalah untuk dapat membandingkan efisiensi suatu bagian dengan bagian yang lain di dalam perusahaan yang bersangkutan.

- Analisa Return On Asset juga dapat digunakan untuk mengukur profitabilitas dari masing-masing produk yang dihasilkan perusahaan dengan menggunakan product cost system yang baik, modal dan biaya dapat dialokasikan kepada berbagai produk yang dihasilkan oleh perusahaan yang bersangkutan, sehingga dengan demikian akan dapat dihitung profitabilitas dari masing-masing produk. Dengan demikian manajemen akan dapat mengetahui produk mana yang mempunyai profit potential.

- Return On Assets selain berguna untuk keperluan kontrol, juga berguna untuk keperluan perencanaan. Misalnya Return On Assets dapat digunakan sebagian dasar untuk pengembalian keputusan kalau perusahaan akan mengadakan ekspansi.

\section{c. Faktor-faktor yang mempengaruhi Return on Assets}

Menurut Kasmir (2012:203), menjelaskan bahwa yang mempengaruhi Return on Assets (ROA) adalah hasil pengembalian atas investasi atau yang disebut sebagai Return on Assets (ROA) dipengaruhi oleh margin laba bersih dan perputaran total aktiva karena apabila ROA rendah itu 
disebabkan oleh rendahnya margin laba yang diakibatkan oleh rendahnya margin laba bersih yang diakibatkan oleh rendahnya perputaran total aktiva.

Profitabilitas adalah rasio yang mengukur kemampuan perusahaan menghasilkan laba. Return on Assets (ROA) termasuk salah satu rasio profitabilitas. Faktor - faktor yang mempengaruhi rasio return on asset ada beberapa rasio antara lain: rasio perputaran kas, rasio perputaran piutang, dan rasio perputaran persediaan.

\section{- Perputaran Kas (Cash Turnover)}

Dengan menghitung tingkat perputaran kas akan diketahui sampai berapa jauh tingkat efisiensi yang dapat dicapai perusahaan dalam upaya mendayagunakan persediaan kas yang ada untuk mewujudkan tujuan perusahaan. Menurut Kasmir (2008:140) menyatakan rasio perputaran kas (cash turnover) berfungsi untuk mengukur tingkat kecukupuan modal kerja perusahaan yang dibutuhkan untuk membayar tagihan dan membiayai penjualan. Artinya rasio ini digunakan untuk mengukur tingkat ketersediaan kas untuk membayar tagihan (utang) dan biaya-biaya yang berkaitan dengan penjualan.

- Perputaran Piutang (Receivable Turnover)

Berhasil tidaknya kebijakan penjualan kredit suatu perusahaan dapat dilakukan dengan cara melihat tingkat perputaran piutang. Menurut Kasmir (2015:176) Perputaran piutang (Receivable Turn Over) merupakan rasio yang digunakan untuk mengukur berapa lama penagihan piutang selama satu periode atau berapa kali hdana yang ditanam dala piutang ini berputar dalam satu periode. Dari definisi tersebut dapat diketahui bahwa rasio perputaran piutang yang tinggi mencerminkan kualitas piutang yang semakin baik. Tinggi rendahnya perputaran piutang tergantung pada besar kecilnya modal yang diinvestasikan dalam piutang. Semakin cepat perputaran piutang berarti semakin cepat modal kembali.

- Perputaran Persediaan (Inventory Turnover)

Persediaan merupakan unsur dari aktiva lancar yang merupakan unsur yang aktif dalam operasi perusahaan yang secara terus menerus diperoleh, diubah dan kemudian dijual kepada konsumen. Untuk mempercepat pengembalian kas melalui penjualan maka diperlukan suatu perputaran persediaan yang baik. Menurut Kasmir (2015:180) Inventory TurnOver merupakan rasio yang digunakan untuk mengukur berapa kali dana yang ditanam dalam persediaan (Inventory) ini berputar dalam satu periode. Pada prinsipnya perputaran persediaan mempermudah atau memperlancar jalannya operasi perusahaan yang harus dilakukan secara berturut-turut untuk memproduksi barang-barang serta mendistribusikannya kepada 
pelanggan. Semakin tinggi tingkat perputaran persediaan tersebut maka jumlah modal kerja yang dibutuhkan semakin rendah.

\section{E. Hipotesis Penelitian}

Berdasarkan kerangka pemikiran diatas sesuai dengan tujuan penelitian untuk menjawab pertayaan penelitian, maka hipotesis yang diuji adalah sebagai berikut:

1. Ho $: \beta 1=0$ : Diduga tidak terdapat pengaruh antara Current Ratio dengan Rentabilitas Ekonomi (Return On Assets) pada PT. Electronic City, Tbk.

Ha: $\beta 1 \neq 0$ : Diduga terdapat pengaruh antara Current Ratio dengan Rentabilitas (ROA) Return On Assets pada PT. Electronic City, Tbk.

2. Ho : $\beta 2=0$ : Diduga tidak terdapat pengaruh antara Debt to Assets Ratio dengan Rentabilitas Ekonomi (Return On Assets) pada PT. Electronic City, Tbk.

Ha : $\beta 2 \neq 0$ : Diduga terdapat pengaruh antara Debt to Assets Ratio dengan Rentabilitas (ROA) Return On Assets pada PT. Electronic City, Tbk.

3. Ho : $\beta 3=0$ : Diduga tidak terdapat pengaruh antara Current Ratio dan Debt to Assets Ratio dengan Rentabilitas Ekonomi (Return On Assets) pada PT. Electronic City, Tbk.

Ha : $\beta 3 \neq 0$ : Diduga terdapat pengaruh antara Current Ratio dan Debt to Assets Ratio dengan Rentabilitas (ROA) Return On Assets pada PT. Electronic City, Tbk.

\section{F. Metode Penelitian}

Penelitian ini dilakukan pada PT.Elektronik City, Penelitian ini adalah posisi keuangan pada laporan keuangan PT.Elektronik City tahun 2008-2017.

Ruang lingkup pada penelitian ini penulis membatasi pada objek- objek yang meliputi pengetahuan umum tentang pengaruh Current Ratio Dan Debt to Assets Ratio Terhadap pertumbuhan laba pada PT.Elektronik City selama 2008-2017. Adapun untuk mengukur pengaruh tingkat keuntungan perusahaan pada setiap periode nya ke periode berikutnya yang beracuan pada laporan keuangan PT.Elektronik City tahun 2008-2017.Data yang digunakan adalah menggunakan data primer dan data skunder. Data primer yang berupa wawancara beberapa dan berupa penyebaran kuesioner sedangkan dari data sekunder berupa keadaan umum objek penelitian (Rumah Sakit Syarif Hidayatullah Jakarta).

Waktu Penelitian terhitung mulai dari bulan September sampai November 2018, penelitian ini dilaksanakan secara bertahap mulai dari pengajuan proposal, konsultasi dan pengolahan data. Sementara data laporan keuangan yang diambil adalah neraca dan laba rugi periode 2008 sampai dengan 2017. Penelitian yang digunakan peneliti dalam menyusun skripsi ini adalah penelitian yang bersifat deskriptif kuantitatif, yaitu menggambarkan permasalahan yang dihadapi oleh perusahaan terhadap kinerja perusahaan dari segi keuangan. 


\section{G. HASIL DAN PEMBAHASAN}

\section{a. Gambaran Umum PT Electronic City Indonesia Tbk}

\section{Sejarah PT Electronic City Indonesia Tbk.}

PT Electronic City Indonesia Tbk. ("Electronic City") merupakan salah satu dari pelopor perusahaan ritel produk elektronik modern di Indonesia. Berdiri sejak tahun 2001 dan membuka toko standalone sekaligus toko pertama (flagship store) di Sudirman Central Business District (SCBD). Electronic City memperluas jaringan toko di luar Jabodetabek dengan membuka toko pertama di Denpasar di tahun 2004 dan di Sumatera yang terletak di Medan, Sumatera Utara di tahun 2007. Electronic City resmi menjadi perusahaan terbuka pada tanggal 3 Juli 2013 dan tercatat di PT Bursa Efek Indonesia (kode saham ECII). Electronic City melepas 333. 333.000 saham atau sebanyak $25 \%$ dari modal ditempatkan dan disetor penuh setelah penawaran um um dengan harga penawaran Rp 4.050 per saham. Sampai dengan September 2018, Electronic City telah mengoperasikan 53 toko yang tersebar di beberapa kota besar di pulau Jawa, Bali, Sumatera, Kalimantan dan Sulawesi. Electronic City menawarkan produk yang beragam dalam empat kategori utama yaitu: audio-video, peralatan rumah tangga, telepon selular dan gadget, peralatan TI dan perlengkapan kantor. Dalam menjalankan kegiatan operasionalnya Electronic City juga didukung oleh 11 gudang distribusi yang berada di Jakarta, Bogor, Bandung, Tangerang, Solo, Solo, Medan, Denpasar, Pontianak, Balikpapan dan Kendari. Electronic City menerapkan dual-branding strategy melalui dua konsep toko Electronic City Store (EC Store) dan Electronic City Outlet (EC Outlet) sebagai metode pemasaran untuk target segmen konsumen yang berbeda. Electronic City juga meluncurkan platform e-commerce melalui situs resmi Perseroan dalam upaya untuk memperkuat citra Perseroan dan menjaring konsumen yang lebih memilih untuk membeli produk secara online. Electronic City Stores (EC Stores) - Tampilan toko dan penyajian produk EC Stores menggunakan konsep berwarna biru. EC Stores memiliki target utama konsumen kelas menengah ke atas. Pada umumnya, luas area penjualan bruto berkisar antara 600 sampai dengan $2.500 \mathrm{~m} 2$. Sampai dengan Juni 2014, Electronic City mengoperasikan 45 EC Stores yang berada di lokasi strategis di dalam mall, ruko dan berdiri sendiri (standalone). Total luas area penjualan bruto $45 \mathrm{EC}$ Stores adalah $55.925 \mathrm{~m} 2$. Electronic City Outlet (EC Outlet) - Tampilan toko dan penyajian produk EC Outlet menggunakan konsep berwarna merah. Memiliki target utama konsumen tingkat pemula dan kelas menengah. Pada umumnya, luas area penjualan bruto berkisar antara 350 sampai dengan 700 m2. Sampai dengan Juni 2014, Electronic City mengoperasikan 16 EC Outlet 
Jurnal Semarak,Vol. 3,No.1, Februari 2020, Hal (1- 19)

@Prodi Manajemen Fakultas Ekonomi Universitas Pamulang

yang berada di lokasi strategis di dalam mal dan ruko. Total luas area penjualan bruto $16 \mathrm{EC}$ Outlet adalah $8.083 \mathrm{~m} 2$.

\section{Visi Dan Misi PT Electronic City Indonesia Tbk}

a. Visi:

Mengembangkan toko ritel elektronik modern dengan konsep pameran untuk memberikan pelayanan yang terbaik, didukung oleh sumber daya manusia yang kompeten dan mitra bisnis profesional untuk menambah kepuasan konsumen.

b. Misi:

Untuk menjadi perusahaan terkemuka di Indonesia dalam bisnis ritel elektronik dengan jaringan toko modern berskala luas dan didukung oleh layanan terbaik dan fasilitas lengkap.

\section{b. Pembahasan dan Hasil Penelitian}

\section{Analisis Statistik}

- Uji Asumsi Klasik

a) Uji Normalitas

Hasil pengujian normalitas data pada variabel Current Ratio (CR) dan Debt to Assets Ratio (DAR) terhadap Return On Assets (ROA) diperoleh hasil sebagai berikut :

Normal P-P Plot of Regression Standardized Residual

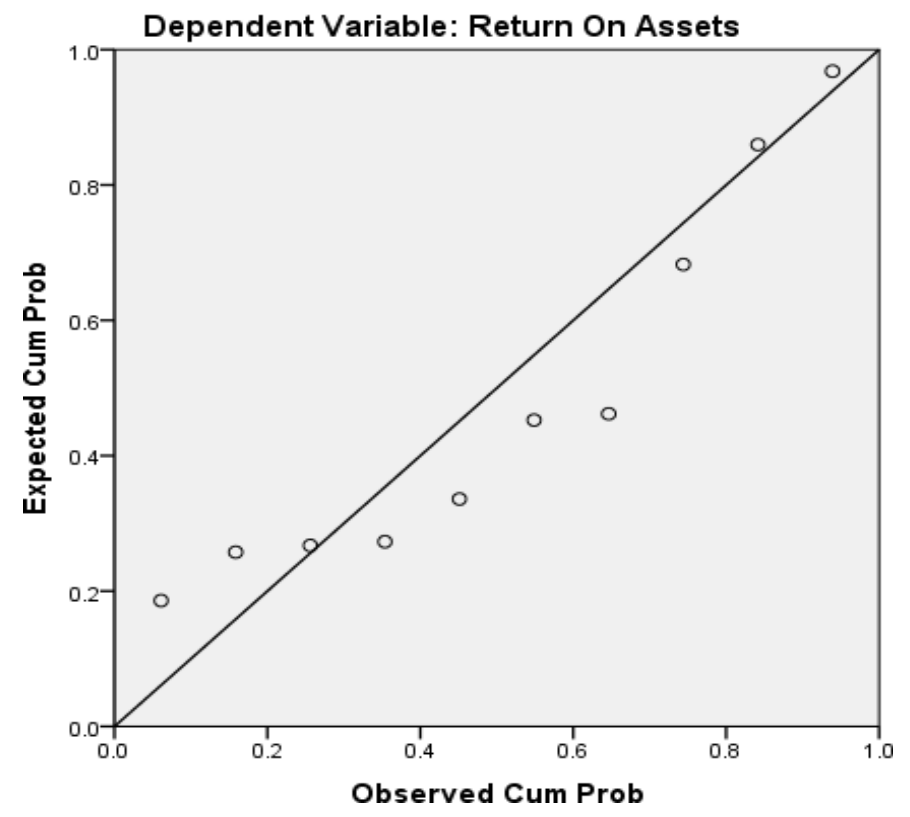

Gambar 4.5

Normal P-Plot

Kesimpulan dari gambar diatas bahwa nilai residualnya terdistribusi secara normal, 
dimana pada gambar tersebut titik- titik nilai residualnya yang ada pada tabel alurnya mengikuti garis diagonal yang menunjukan tingkat normalitas nilai-nilai residualnya yang ada, oleh karna terpenuhinya asumsi normalitas maka penelitian ini dapat dilanjutkan pada analisa statistik selanjutnya.

\section{b) Uji Multikolinearitas}

Tabel 4.4

Hasil Uji Nilai Toleransi dan VIF

\begin{tabular}{|c|c|c|c|}
\hline \multicolumn{4}{|c|}{ Coefficients $^{\mathrm{a}}$} \\
\hline \multicolumn{2}{|c|}{ Model } & \multicolumn{2}{|c|}{ Collinearity Statistics } \\
\hline & & Tolerance & VIF \\
\hline \multirow{3}{*}{1} & (Constant) & & \\
\hline & Current Ratio & .177 & 5.665 \\
\hline & Debt to Assets Ratio & .177 & 5.665 \\
\hline
\end{tabular}

Pengujian yang dilakukan pada model regresi linear berganda, menunjukan nilai VIF Variabel X1 Current Ratio (CR), dan Variabel X2 Debt to Assets Ratio (DAR). Nilai VIF pada variabel Current Ratio (CR) sebesar 5.665 dan pada variabel Debt to Assets Ratio (DAR) sebesar 5.665. semua nilai VIF pada model regresi linear berganda menunjukkan hasil VIF $<10$, hal ini dikatakan bahwa dalam penelitian ini tidak terdapat kendala Multikolinearitas. 


\section{c) Uji Heteroskedastisitas}

Uji Heteroskedastisitas ini dapat dilihat pada gambar dibawah ini :

Scatterplot

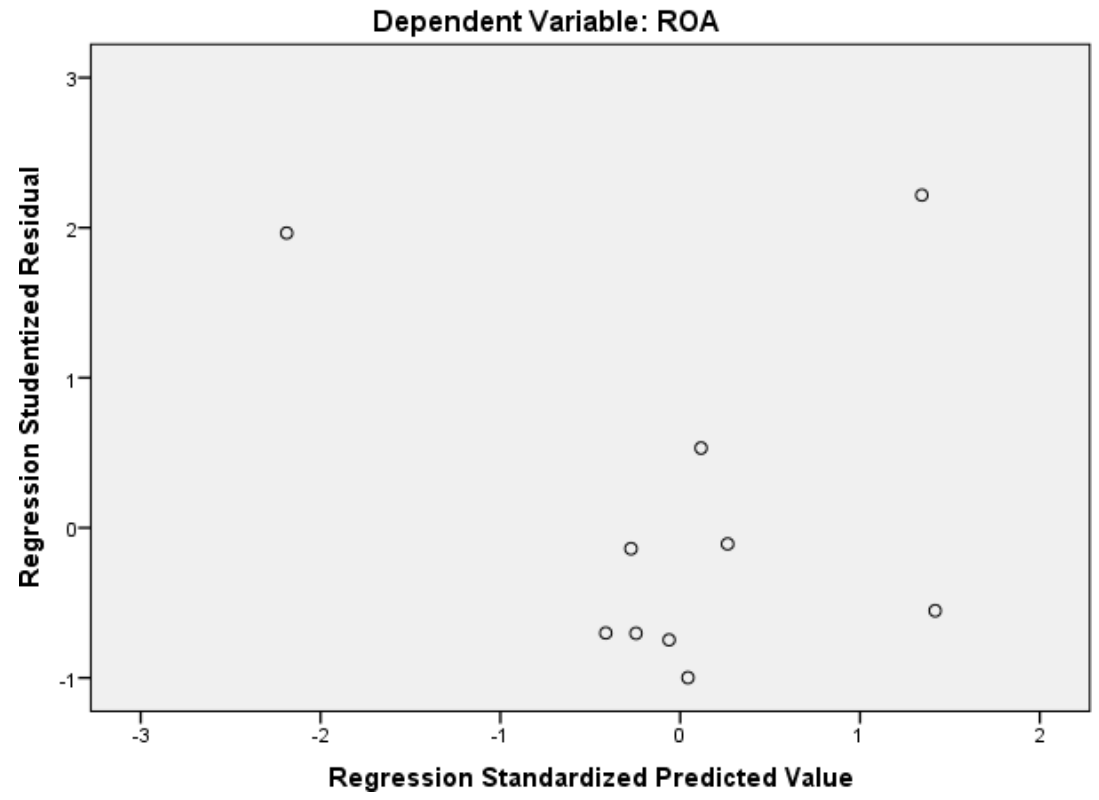

\section{Gambar 4.6}

Scatterplot

Berdasarkan gambar hasil pengelolaan SPSS (Scatterplot) diatas maka dapat dilihat titik residual menyebar secara acak merata, tidak terjadi adanya pengelomnpokan data yang signifikan, sehingga data ini telah memenuhi syarat heteroskedastisitas, yang artinya data dapat dilanjutkan dalam pengujian regresi. 
Jurnal Semarak,Vol. 3,No.1, Februari 2020, Hal (1- 19)

\section{d) Uji Autokorelasi}

Uji Autokorelasi bertujuan untuk menguji apakah variabel X dan Y saling mengganggu. Untuk melihat terjadi atau tidaknya autokorelasi dapat diukur dengan menggunakan nilai Durbin Watson. Dimana apabila Durbin Watson berkisar antara 1,5 sampai 2,5 maka variabel penelitian tidak terjadi autokorelasi.

Berikut dapat dilihat hasil uji Durbin Watson pada tabel dibawah ini :

Tabel 4.5

\section{Hasil Uji Autokorelasi}

\begin{tabular}{|l|c|r|r|r|r|}
\hline Model & $\mathrm{R}$ & $\begin{array}{c}\mathrm{R} \\
\text { Square }\end{array}$ & $\begin{array}{c}\text { Adjusted R } \\
\text { Square }\end{array}$ & $\begin{array}{c}\text { Std. Error of the } \\
\text { Estimate }\end{array}$ & $\begin{array}{c}\text { Durbin- } \\
\text { Watson }\end{array}$ \\
\hline 1 & $.636^{\mathrm{a}}$ & .404 & .234 & 7.40300 & 1.732 \\
\hline
\end{tabular}

a. Predictors: (Constant), Debt to Assets Ratio, Current Ratio

b. Dependent Variable: Return On Assets

(Sumber : Output SPSS 20,2018, data diolah penulis)

Hasil perhitungan nilai Durbin Watson pada model adalah

sebesar 1.732 dengan demikian bahwa dalam penelitian ini tidak terjadi Autokorelasi.

\section{e) Uji Regresi Berganda}

Analisis regresi berganda merupakan hubungan antara variabel dependen dengan variabel independen dengan menggunakan persamaan linear. Persamaan regresi linear berganda yaitu Pengaruh Current Ratio, Debt to Assets Ratio terhadap Return On Assets dapat 
sebagai berikut :

Tabel 4.6

Hasil Uji Regresi Berganda

\begin{tabular}{|c|c|c|c|c|c|c|}
\hline \multicolumn{7}{|c|}{ Coefficients $^{\mathrm{a}}$} \\
\hline \multirow{2}{*}{\multicolumn{2}{|c|}{ Model }} & \multicolumn{2}{|c|}{$\begin{array}{l}\text { Unstandardized } \\
\text { Coefficients }\end{array}$} & \multirow{2}{*}{$\begin{array}{c}\begin{array}{r}\text { Standardized } \\
\text { Coefficients }\end{array} \\
\text { Beta }\end{array}$} & \multirow[t]{2}{*}{$\mathrm{t}$} & \multirow[t]{2}{*}{ Sig. } \\
\hline & & B & $\begin{array}{l}\text { Std. } \\
\text { Error }\end{array}$ & & & \\
\hline \multirow{5}{*}{1} & (Constant) & 32.756 & 13.324 & & 2.458 & .044 \\
\hline & Current & 026 & 012 & 1505 & 167 & 067 \\
\hline & Ratio & & & & & \\
\hline & Debt to & 201 & 155 & 1200 & 1071 & 102 \\
\hline & Assets Ratio & & & & & \\
\hline
\end{tabular}

a. Dependent Variable: Return On Assets

(Sumber : Output SPSS 20,2018, data diolah penulis)

Pada tabel coefficients dapat diketahui nilai dalam kolom B, baris pertama menunjukan konstanta $(\alpha)$ dan ba7ris selanjutnya menunjukan koefisien variabel-variabel independen $\left(b_{1}, b_{2}\right)$. Dengan melihat tabel di atas, dapat disusun persamaan regresi berganda sebagai berikut :

$$
\mathrm{Y}=32,756-0,026 \mathrm{X}_{1}-\mathbf{0 , 2 9 1 X _ { 2 }}
$$

Keterangan :

$\mathrm{Y} \quad=$ Return On Assets

A $\quad=$ Konstanta

$\mathrm{B}_{1}=$ Koefisien Regresi Variabel $\mathrm{X}_{1}$

$\mathrm{B}_{2}=$ Koefisien Regresi Variabel $\mathrm{X}_{2}$

$\mathrm{X}_{1}=$ Current Ratio

$\mathrm{X}_{2}=$ Debt to Assets Ratio 
Dari persamaan tabel di atas, uji regresi berganda dapat diinterprestasikan sebagai berikut :

1. Konstanta $(\alpha)$

Nilai konstanta bertanda positif 32,756 yang menunjukkan apabila variabel Current Ratio (CR) dan Debt to Assets Ratio (DAR) tidak ada perubahan atau sama dengan 0 maka akan meningkatkan Return On Assets (ROA) sebesar 32,756.

\section{Current Ratio $\left(\mathrm{X}_{1}\right)$ terhadap Return On Assets (Y)}

Nilai koefisien Current Ratio (CR) untuk variabel X1 sebesar sebesar -0,026 dan bertanda negatif. Hal ini mengandung arti bahwa setiap kenaikan Current Ratio (CR) 1\% maka Return On Assets (Y) akan turun sebesar -0,026 dengan asumsi bahwa variabel bebas yang lain dari model regresi adalah tetap.

3. Debt to Assets Ratio (X2) terhadap Return On Assets (Y)

Nilai koefisien Debt to Assets Ratio (DAR) untuk variabel X2 sebesar -0,291 dan bertanda negatif. Hal ini mengandung arti bahwa setiap kenaikan Debt to Assets Ratio (DAR) $1 \%$ maka Return On Assets (Y) akan turun sebesar -0,291 dengan asumsi bahwa variabel bebas yang lain dari model regresi adalah tetap. 


\section{f) Uji Korelasi Berganda}

Tabel 4.7

Hasil Korelasi Berganda

\begin{tabular}{|l|c|r|r|r|r|}
\hline Model & $\mathrm{R}$ & $\mathrm{R}$ & \multicolumn{1}{|c|}{$\begin{array}{c}\text { Adjusted R } \\
\text { Square }\end{array}$} & $\begin{array}{c}\text { Std. Error of the } \\
\text { Estimate }\end{array}$ & $\begin{array}{c}\text { Durbin- } \\
\text { Watson }\end{array}$ \\
\hline 1 & $.636^{\mathrm{a}}$ & .404 & .234 & 7.40300 & 1.732 \\
\hline
\end{tabular}

a. Predictors: (Constant), Debt to Assets Ratio, Current Ratio

b. Dependent Variable: Return On Assets

(Sumber : Output SPSS 20,2018, data diolah penulis)

Hasil korelasi berganda tersebut dapat dilihat pada tabel diatas bahwa perhitungan korelasi berganda (R) adalah sebesar 0,636 atau 63,6\%. Hal ini menunjukkan keeratan hubungan antara variabel Current Ratio (CR) dan Debt to Assets Ratio (DAR) terhadap Return On Assets (ROA) mempunyai hubungan yang kuat.

\section{g) Koefisien Determinasi}

Tabel 4.8

Hasil Koefisien Determinasi

\begin{tabular}{|l|c|r|r|r|c|}
\hline Model & $\mathrm{R}$ & $\begin{array}{c}\mathrm{R} \\
\text { Square }\end{array}$ & $\begin{array}{c}\text { Adjusted R } \\
\text { Square }\end{array}$ & $\begin{array}{c}\text { Std. Error of the } \\
\text { Estimate }\end{array}$ & $\begin{array}{c}\text { Durbin- } \\
\text { Watson }\end{array}$ \\
\hline 1 & $.636^{\mathrm{a}}$ & .404 & .234 & 7.40300 & 1.732 \\
\hline
\end{tabular}

a. Predictors: (Constant), Debt to Assets Ratio, Current Ratio

b. Dependent Variable: Return On Assets

(Sumber : Output SPSS 20,2018, data diolah penulis)

Uji koefisien determinasi dapat dilihat dari R Square. Dari hasil pengolahan data menggunakan SPSS 20 dapat dilihat bahwa nilai $\mathrm{R}$ Square menunjukkan angka sebesar 0.404 yang berarti bahwa variabel $\mathrm{X}_{1}$ Current Ratio (CR) dan $\mathrm{X}_{2}$ Debt to Assets Ratio (DAR) 
JURNAL ILVIAH $\quad$ P-ISSN 2615-6849, E-ISSN 2622-3686

Jurnal Semarak,Vol. 3,No.1, Februari 2020, Hal (1- 19)

@Prodi Manajemen Fakultas Ekonomi Universitas Pamulang

berpengaruh terhadap Return On Assets (ROA) sebesar 40,4\% 
Jurnal Semarak,Vol. 3,No.1, Februari 2020, Hal (1- 19)

@Prodi Manajemen Fakultas Ekonomi Universitas Pamulang

sedangkan sisanya 59,6\% dipengaruhi oleh faktor lain yang tidak

dijelaskan dalam penelitian ini.

\section{Analisis Hipotesis}

\section{a. Uji Signifikansi Parsial (Uji t)}

Pengujian ini dilakukan untuk mengetahui apakah secara parsial variabel independen mempunyai pengaruh secara signifikan terhadap variabel dependennya. Data yang dihasilkan atas analisis variabel dependen dan variabel independennya sebagai berikut :

\section{Tabel 4.9}

\section{Hasil Uji t}

\section{Coefficients $^{\mathrm{a}}$}

\begin{tabular}{|c|c|c|c|c|c|c|}
\hline \multirow[t]{2}{*}{ Model } & & \multicolumn{2}{|c|}{$\begin{array}{c}\text { Unstandardized } \\
\text { Coefficients }\end{array}$} & \multirow{2}{*}{$\begin{array}{c}\begin{array}{r}\text { Standardized } \\
\text { Coefficients }\end{array} \\
\text { Beta }\end{array}$} & \multirow[t]{2}{*}{$\mathrm{t}$} & \multirow[t]{2}{*}{ Sig. } \\
\hline & & B & $\begin{array}{l}\text { Std. } \\
\text { Error }\end{array}$ & & & \\
\hline \multirow{4}{*}{1} & (Constant) & 32.756 & 13.324 & & 2.458 & .044 \\
\hline & Current Ratio & -.026 & .012 & -1.505 & -2.167 & .067 \\
\hline & Debt to & & & & & \\
\hline & Assets Ratio & -.291 & | 155. & -1.300 & -1.871 & .103 \\
\hline
\end{tabular}

Dari tabel diatas diketahui bahwa variabel X1 Current Ratio (CR) terhadap variabel Y Return On Assets (ROA) menunjukkan bahwa Current Ratio (CR) memiliki $t_{\text {hitung }}$ sebesar -2.167 sedangkan $t_{\text {tabel }}$ sebesar 2,306 sehingga $t_{\text {hitung }}<t_{\text {tabel }}$. Dengan nilai signifikan sebesar 0.067 artinya lebih besar dari taraf signifikan yaitu 0.05. dengan demikian maka $\mathrm{H}_{\mathrm{o}}$ diterima dan $\mathrm{H}_{1}$ ditolak, sehingga dapat diartikan 
Jurnal Semarak,Vol. 3,No.1, Februari 2020, Hal (1- 19)

@Prodi Manajemen Fakultas Ekonomi Universitas Pamulang

tidak terdapat pengaruh signifikan antara Current Ratio (CR) terhadap Return On Assets (ROA).

Hasil Uji t antara variabel $\mathrm{X}_{2}$ Debt to Assets (DAR) terhadap variabel Y Return On Assets (ROA) menunjukkan bahwa Debt to Assets Ratio (DAR) memiliki thitung sebesar -1.871 sedangkan $t_{\text {tabel }}$ sebesar 2,306 sehingga $t_{\text {hitung }}<t_{\text {tabel }}$. Dengan nilai signifikan sebesar 0.103 artinya lebih besar dari taraf signifikan yaitu 0.05 . dengan demikian maka $\mathrm{H}_{\mathrm{o}}$ diterima dan $\mathrm{H}_{2}$ ditolak, sehingga dapat diartikan tidak terdapat pengaruh signifikan antara Debt to Assets Ratio (DAR) terhadap Return On Assets (ROA).

\section{b. Uji Signifikansi Simultan (Uji F)}

Uji $\mathrm{F}$ digunakan untuk menghitung apakah secara bersama-sama (simultan) variabel independen yang digunakan dalam penelitian berpengaruh signifikan terhadap variabel dependennya.

Tabel 4.10

Hasil Uji F

\begin{tabular}{|l|r|r|r|r|r|}
\hline Model & \multicolumn{1}{|c|}{ ANOVA $^{\text {Sa }}$} \\
& Squares & df & Mean Square & F & Sig. \\
\hline Regression & 260.150 & 2 & 130.075 & 2.373 & $.163^{\mathrm{b}}$ \\
Residual & 383.631 & 7 & 54.804 & & \\
Total & 643.781 & 9 & & & \\
\hline
\end{tabular}

a. Dependent Variable: Return On Assets

b. Predictors: (Constant), Debt to Assets Ratio, Current Ratio

(Sumber : Output SPSS 20,2018, data diolah penulis)

Hasil Uji F antara variabel bebas $\mathrm{X}_{1}$ Current Ratio (CR) dan $\mathrm{X}_{2}$ 
JURNAL ILVIAH $\quad$ P-ISSN 2615-6849, E-ISSN 2622-3686

Jurnal Semarak,Vol. 3,No.1, Februari 2020, Hal (1- 19)

@Prodi Manajemen Fakultas Ekonomi Universitas Pamulang

Debt to Assets Ratio (DAR) secara bersama-sama terhadap variabel 
Jurnal Semarak,Vol. 3,No.1, Februari 2020, Hal (1- 19)

@Prodi Manajemen Fakultas Ekonomi Universitas Pamulang

terikat Y Return On Assets (ROA) menunjukkan nilai $F_{\text {hitung }}$ sebesar $2.373<$ nilai $\mathrm{F}_{\text {tabel }}$ sebesar 4.74 dengan nilai signifikansi sebesar 0.163 lebih besar dari tarif signifikan yang ditentukan yaitu 0.05 . Dengan demikian maka $\mathrm{H}_{\mathrm{o}}$ diterima dan $\mathrm{H}_{3}$ ditolak, sehingga dapat disimpulkan bahwa secara simultan Current Ratio (CR) dan Debt to Assets Ratio (DAR) tidak terdapat pengaruh signifikan terhadap Return On Assets (ROA) pada PT. Electronic City, Tbk. Periode 20082017.

\section{Analisa Deskriptif}

Berdasarkan hasil penelitian, dapat disimpulkan bahwa :

Uji Asumsi Klasik

Berdasarkan data yang diperoleh dari hasil pengujian asumsi klasik, bahwa data berdistribusi normal. Tidak ada masalah heteroskedastisitas, tidak ada masalah multikolenearitas dan terbebas dari autokorelasi.

Persamaan Regresi Berganda

Berdasarkan data yang diperoleh dari hasil pengujian persamaan regresi berganda didapat nilai :

$\mathrm{Y}=32,756-0,026 \mathrm{X}_{1}-0,291 \mathrm{X}_{2}$, artinya jika Current Ratio (CR) dan Debt to Assets Ratio (DAR) menurun satu satuan maka jumlah Return On Assets (ROA) sebesar 0,026 dan 0,291. Jika Current Ratio (CR) dan Debt to Assets Ratio 
P-ISSN 2615-6849, E-ISSN 2622-3686

Jurnal Semarak,Vol. 3,No.1, Februari 2020, Hal (1- 19)

@Prodi Manajemen Fakultas Ekonomi Universitas Pamulang

(DAR) sebesar -0 maka jumlah Return On Assets (ROA)

sebesar 32,756.

Korelasi Berganda

Berdasarkan data yang diperoleh dari hasil korelasi berganda sebesar 63,6\% yang memiliki kriteria kuat.

Koefisien Determinasi

Berdasarkan data yang diperoleh dari hasil koefisien determinasi. Diperoleh nilai $\mathrm{R}^{2}$ sebesar $40,4 \%$ sedangkan sisanya 59,6\% dipengaruhi oleh faktor lain yang tidak dijelaskan dalam penelitian ini.

\section{H. KESIMPULAN DAN SARAN}

\section{a. Kesimpulan}

Berdasarkan dari hasil penelitian dan pembahasan yang telah di uraikan peneliti, maka dapat disimpulkan bahwa :

1. Hasil penelitian secara parsial variabel Current Ratio (CR) tidak berpengaruh terhadap Return On Assets (ROA). Hal ini dibuktikan dengan nilai thitung sebesar $-2,167<t_{\text {tabel }}$ sebesar 2.306 dengan nilai signifikan sebesar $0,067>0,05$. Maka $\mathrm{H}_{\mathrm{o}}$ diterima dan $\mathrm{H}_{1}$ ditolak, sehingga dapat diartikan tidak terdapat pengaruh signifikan antara Current Ratio (CR) terhadap Return On Assets (ROA).

2. Hasil penelitian secara parsial variabel Debt to Assets Ratio (DAR) tidak berpengaruh terhadap Return On Assets (ROA). Hal ini dibuktikan dengan nilai $t_{\text {hitung }}$ sebesar $-1.871<t_{\text {tabel }}$ sebesar 2,306 dengan nilai signifikan sebesar 0,103>0,05. Maka $\mathrm{H}_{\mathrm{o}}$ diterima dan $\mathrm{H}_{2}$ ditolak, sehingga dapat diartikan tidak terdapat pengaruh signifikan antara Debt to Assets Ratio (DAR) terhadap Return On Assets (ROA).

3. Hasil penelitian secara simultan variabel Current Ratio (CR) dan Debt to Assets Ratio (DAR) terhadap Return On Assets (ROA) tidak terdapat pengaruh signifikan. Hal ini dapat ditunjukkan dengan nilai $F_{\text {hitung }}$ sebesar $2,373<$ nilai $F_{\text {tabel }}$ sebesar 4.74 dengan tingkat signifikasi $0,163>0,05$ 
Maka $\mathrm{H}_{\mathrm{o}}$ diterima dan $\mathrm{H}_{3}$ ditolak, sehingga dapat diartikan tidak terdapat pengaruh signifikan antara Current Ratio (CR) dan Debt to Assets Ratio (DAR) secara bersamasama terhadap Return On Assets (ROA).

\section{b. Saran}

Berdasarkan kesimpulan diatas, maka peneliti dapat memberikan saran sebagai berikut :

1. Bagi Perusahaan

Bagi perusahaan PT. Electronic City Tbk, sebaiknya meningkatkan pengelolaan keuangan perusahaan dengan meningkatkan rasio-rasio keuangan perusahaan seperti Current Ratio (CR), Debt to Assets Ratio (DAR) dan Return On Assets (ROA) agar investor tertarik untuk berinvestasi.

2. Bagi Investor

Bagi investor atau calon investor agar dalam menilai kinerja perusahaan yang menjadi sasaran investasi, tidak hanya memperhatikan Return On Assets (ROA) perusahaan tetapi juga sebaiknya memperhatikan hal-hal yang dapat mempengaruhi sehingga pengambilan keputusan investasi tepat.

3. Bagi Peneliti

Bagi peneliti selanjutnya, diharapkan mengembangkan peneliti ini dengan menambahkan variabel independen yang dapat berpengaruh secara parsial dan simultan terhadap Return On Assets (ROA).

\section{DAFTAR PUSTAKA}

Abdurahman, Muhidin dan Somantri. 2011. Dasar-dasar Metode Statistika Untuk Penelitian. Jakarta : Salemba Empat

Brigham dan Houston. 2010. Dasar-dasar Manajemen Keuangan Buku 1 (Edisi 11). Jakarta : Salemba Empat.

Engkoswara. 2010. Paradigma Manajemen Pendidikan. Bandung: Yayasan Amal Keluarga.

Fahmi, Irham. 2014. Pengantar Manajemen Keuangan. Bandung: Alfabeta Ghozali, Imam. 2011. Aplikasi Analisis Multivariate dengan Program SPSS.

Semarang : Badan Penerbit Universitas Diponegoro.

Ghozali, Imam. 2016. Aplikasi Analisis Multivariate dengan Program SPSS. Edisi Kedelapan. Semarang : Badan Penerbit Universitas Diponegoro.

Hasibuan, Malayu, SP. 2009. Manajemen: Dasar, Pengertian dan Masalah.

Jakarta:Bumi Aksara.

Ismail, Solihin. 2009. Pengantar Manajemen. Jakarta: Erlangga 
Jurnal Semarak,Vol. 3,No.1, Februari 2020, Hal (1- 19)

@Prodi Manajemen Fakultas Ekonomi Universitas Pamulang

I Made Sudana. 2011. Manajemen Keuangan Perusahaan. Erlangga, Jakarta Jogiyanto, 2014.Teori Portofolio dan Analisis Investasi (Edisi ke 10). Yogyakarta :BPFE.

Kasmir. 2015. Analisis Laporan Keuangan. Jakarta:PT. Raja Grafindo Persada. Kasmir. 2017. Pengantar Manajemen Keuangan. Jakarta : Prenadamedia Group Kamaludin. 2011. Manajemen Keuangan. Bandung: Mandar Maju.

Muhammad. 2009. Metode Penelitian. Jakarta: Ghalia Indonesia.

Purnomo, S., \& Pasaribu, V. L. D. (2019). PERGERAKAN HARGA SAHAM PT ADARO ENERGY TBK (ADRO) PADA PENGUMUMAN DIVIDEN INTERIM

TAHUN BUKU

2018. Jurnal

Ekonomi

Efektif, 2(1). 
Jurnal Semarak,Vol. 3,No.1, Februari 2020, Hal (1- 19)

@Prodi Manajemen Fakultas Ekonomi Universitas Pamulang

Safroni, Ladzi. 2012. Manajemen dan Reformasi Pelayanan Publik dalam Konteks Birokrasi Indonesia. Surabaya : Aditya Media Publishing

Syafrida Hani.2015. Teknik Analisa Laporan Keuangan. Medan: UMSU PRESS.

Syamsuddin, Lukman. 2006. Manajemen Keuangan Perusahaan: Konsep Aplikasi dalam Perencanaan, Pengawasan, dan Pengambilan Keputusan. Jakarta:PT Raja Grafindo Persada.

Syamsuddin. 2009. Manajemen Keuangan Perusahaan. Jakarta: PT. Raja Grafindo Persada.

Subramanyam dan John J. Wild. 2012. Analisis Laporan Keuangan. Jakarta: Salemba Empat.

Robbins, Stephen P. dan Coulter, Mary. (2010). Manajemen (Edisi Ke 10).

Jakarta:Erlangga

Sugiyono. 2017.Metode Penelitian Pendidikan Pendekatan Kuantitatif,Kualitatif Dan $R \& D$.Bandung: Alfabeta.

Sutrisno. 2013. Manajemen Keuangan Teori, Konsep dan Aplikasi

.Yogyakarta:Ekonisia

Tandelilin, Eduardus. 2010. Portofolio dan Investasi Teori dan Aplikasi. Edisi pertama. Yogyakarta : Kanisius

Terry, George. 2005. Dasar-Dasar Manajemen, Jakarta: PT. Bumi Aksara Usman, Husaini. 2013. Manajemen Teori, Praktik, dan Riset Pendidikan (Edisi

Ke 4) Jakarta Timur: Bumi Aksara. 
Jurnal Semarak,Vol. 3,No.1, Februari 2020, Hal (1- 19)

@Prodi Manajemen Fakultas Ekonomi Universitas Pamulang

\section{$\underline{\text { Sumber Skripsi : }}$}

Amaliya Utami, 2018. Pengaruh Current Ratio, Debt to Equity Ratio, Terhadap Return On Assets pada perusahaan industri kosmetik yang terdaftar di Bursa Efek Indonesia. Manajemen, Universitas Pamulang

Ari Tri Yunita, 2015. Analisis Pengaruh Debt To Equity Ratio, Current Ratio Dan Total Assets Turn Over Terhadap Return On Assets. Manajemen, Universitas Pamulang. Manajemen, Universitas Pamulang

Desi Ria Anggraeni, 2017. Pengaruh Modal Kerja dan Current Ratio terhadap Return On Assets pada perusahaan industri kosmetik yang terdaftar di Bursa Efek Indonesia. Manajemen, Universitas Pamulang

Hartono, 2015. Pengaruh Current Ratio Dan Debt To Equity Ratio Terhadap Profitabilitas Pada Perusahaan Manufaktur Sektor Logam Dan Sejenisnya Yang Terdaftar Di Bursa Efek Indonesia Tahun 2009-2013. Manajemen, Universitas Prima Indonesia

Listriyani, 2016. Pengaruh Modal Kerja dan Current Ratio terhadap Return On Assets pada perusahaan industri minuman yang terdaftar di Busa Efek Indonesia. Manajemen, Universitas Pamulang

Siti Nur Asmi, 2018. Pengaruh Modal Kerja dan Current Ratio terhadap Return On Assets pada perusahaan farmasi yang terdaftar di Bursa Efek Indonesia. Manajemen, Universitas Pamulang

Vera Oktaviani, 2016. Pengaruh Current Ratio dan Cash Ratio Terhadap Return On Assets Pada Perusahaan Manufaktur Yang Terdaftar Di Bursa Efek Indonesia. Manajemen, Universitas Pamulang 
Yayan Jajang, 2016. Pengaruh DAR, ROE, dan ROA Terhadap PBV pada perusahaan Yang Terdaftar Di Bursa Efek Indonesia. Manajemen, Universitas Pamulang

Website :

$\underline{\text { www.idx.co.id www.electronic-city.com }}$

I. 